\title{
Perancangan electronic Museum (e-Museum) sebagai Media Promosi Kain Songket Khas Palembang
}

\author{
Vivi Sahfitri ${ }^{\left.1^{*}\right)}$, Muhammad Nasir ${ }^{2}$, Nyimas Sopiah $^{3}$ \\ ${ }^{1}$ Program Studi Manajemen Informatika, Fakultas Ilmu Komputer, Universitas Bina Darma, Palembang \\ ${ }^{2,3}$ Program Studi Teknik Informatika, Fakultas Ilmu Komputer, Universitas Bina Darma, Palembang \\ 1,2,3 Jln. Jend. Ahmad Yani no 3 Palembang, 30264, Indonesia \\ email: 1vivi_sahfitri@binadarma.ac.id, ${ }^{2}$ nasir@binadarma.ac.id, ${ }^{3}$ nyimas.sopiah@binadarma.ac.id
}

Received: 30 Juli 2018; Revised: 2 Oktober 2018; Accepted: 20 Oktober 2018

Copyright @2018, Politeknik Harapan Bersama, Tegal

\begin{abstract}
Songket is a work of art which is a traditional fabric that is widely used in a variety of custom events in South Sumatera. Songket is made from a special yarn woven by using traditional weaving equipment. To generate a songket takes at least three months. This is causing a songket produced have the expensive price. In the community of South Sumatra songket is a must in custom events, among others, marriage ceremony, welcome the birth and Circumcision. Songket have various motives that have a specific name with the distinctive characteristics that differentiate between a songket with another. This research aims to design the application e-museum which can be a promotion media so the songket can widely know. The method used in building e museum Applications is ordinary Waterfall SDLC Models or linear sequential model. The result of the design can be implemented into the android-based applications.
\end{abstract}

Abstrak - Songket adalah karya seni yang merupakan kain tradisional yang banyak digunakan dalam berbagai kegiatan adat di Sumatera Selatan. Songket dibuat dari benang khusus yang ditenun dengan menggunakan peralatan tenun yang masih bersifat tradisonal. Untuk menghasilkan satu buah kain songket dibutuhkan waktu paling sedikit tiga bulan. Hal ini yang menyebabkan satu buah kain songket yang dihasilkan dari proses penenunan memiliki harga yang cukup mahal. Dalam masyarakat Sumatera Selatan penggunaan kain songket merupakan suatu keharusan dalam kegiatan adat, antara lain upacara adat perkawinan, marhaban, Khitanan dan lain sebagainya. Songket memiliki berbagai motif yang mempunyai nama khusus dengan karakteristik yang khas yang membedakan antara satu kain dengan kain yang lain. Penelitian ini bertujuan untuk merancang aplikasi $e$-museum yang dapat menjadi media promosi kain songket Palembang agar lebih dikenal masyarakat secara luas. Metode yang digunakan dalam membangun aplikasi $e$-museum adalah Model SDLC Waterfall biasa disebut juga dengan model sekuensial linier yang meliputi tahap tinjauan pustaka, analisa kelemahan, kebutuhan dan kelayakan sistem, perancangan sistem, pembuatan aplikasi, pengujian aplikasi dan implementasi. Hasil dari perancangan dapat diimplementasikan kedalam aplikasi berbasis android yang nantinya dapat menjadi media yang memberikan informasi secara spesifik untuk mengenalkan songket ke masyarakat luas sehingga dapat mendukung pelestarian

*) Corresponding author: (Vivi Sahfitri)

Email: vivi_sahfitri@binadarma.ac.id keberadaan kain songket khas Sumatera Selatan sebagasi dalah satu asset budaya yang dimiliki Bangsa Indonesia.

Kata Kunci - Songket, E-museum, Mobile applications, Waterfall Model, Budaya.

\section{PENDAHULUAN}

Museum merupakan tempat penyimpanan berbagai koleksi baik yang berasal dari alam maupun budaya dan aktivitas yang bertujuan untuk dapat dimanfaatkan seluasluasnya oleh masyarakat umum, maka dapat diartikan bahwa pemanfaatan museum dapat digunakan untuk aktivitas penelitian yang dilakukan di museum, baik terhadap koleksi benda museum, pengunjungnya, masyarakat di sekitar museum, maupun terhadap aktivitas pengelolaannya yang meliputi organisasi, kepemimpinan, sarana dan prasarana, pameran, dan lainnya [1]. Definisi lain menyebutkan bahwa museum adalah sebuah lembaga yang bersifat tetap, tidak mencari keuntungan, melayani masyarakat dan pengembangannya, terbuka untuk umum, yang memperoleh, merawat, menghubungkan dan memamerkan, untuk tujuantujuan studi, pendidikan dan kesenangan, barang-barang pembuktian manusia dan lingkungannya [2]. Koleksi museum dipandang sebagai representasi dari identitas dan akar budaya [3]. Koleksi museum dapat berupa specimen yang berupa karya seni, bebatuan bumi, teknologi, mahkluk hidup dan peninggalan bersejarah lainnya [4].

Songket adalah kain tenun yang menggunakan atau bersulam benang emas atau perak dan dikombinasikan dengan benang-benang berwarna lainnya. Songket yang ditenun dengan menggunakan benang emas memiliki nilai estetika yang lebih dibandingkan dengan kain songket yang ditenun dengan benang biasa [5]. Songket berasal dari kata tusuk atau "cukut" yang sering disingkat dengan istilah sukkit, yang kemudian sering diucapkan dengan kata sungkit sehingga akhirnya berubah menjadi kata "songket" [6]. Songket dapat dihasilkan melalui 2 cara yaitu menggunakan tangan dan menggunakan mesin [7]. 
Songket Palembang memiliki ciri khas yang berbeda dari kain khas daerah lain. Songket Palembang memiliki bermacam-macam jenis antara lain Songket Lepus, Songket Tawur, Songket Tretes, Songket Bungo Pacik, Songket Limar dan songket Kombinasi [8]. Motif dan ragam hias songket sejak zaman dulu hingga sekarang diwariskan secara turun temurun. Saat ini motif-motif songket banyak sekali ragamnya. Terdapat 66 jenis motif songket yang diajukan kepada Ditjen HKI Depkumham RI, akan tetapi hanya 22 jenis motif songket yang terdaftar sebagai jenis ciptaan tenun Khas Palembang [9].

Museum Songket yang ada di Kota Palembang telah berdiri sejak tahun 2012. Museum Songket Palembang tersebut memiliki koleksi-koleksi songket dari berbagai ragam hias dan motif. Selain itu Museum Songket Palembang juga memiliki koleksi alat tenun yang biasa digunakan untuk menenun benang sampai dihasilkan selembar kain songket yang indah. Namun keberadaan Museum Songket Palembang tersebut masih belum banyak diketahui masyarakat secara luas. Masalah lain yang menyebabkan museum songket Palembang tersebut memiliki pengunjung yang sangan minim adalah kebiasaan masyarakat yang tidak begitu tertarik untuk mendatangi museum.

Perkembangan teknologi informasi membawa berbagai manfaat diberbagai bidang kehidupan. Salah satunya adalah untuk mengembangkan Perangkat Lunak yang dapat menjadi electronic museum (e-museum) yang dapat memberikan kemudahan dalam menyampaikan informasi tentang berbagai hal yang berkaitan dengan Kain Tenun Songket Palembang. E-museum merupakan inovasi baru yaitu penggunaan dan pemanfaatan teknologi informasi untuk membantu memandu sesorang untuk mengetahui hal-hal yang ada dalam museum dengan memanfaatkan teknologi mobile berbasis Android. Android adalah sebuah sistem operasi yang dapat diimplementasikan pada perangkat mobile berbasis linux yang mencakup sistem operasi, software yang menghubungkan bagian-bagian yang berbeda pada sebuah aplikasi (Middleware) dan aplikasi [10]. Android menyediakan platform yang bersifat terbuka (berbasis open Source) bagi pengembang dalam menciptakan aplikasi yang dapat digunakan secara luas oleh banyak orang. Sistem Operasi android memiliki dua jenis distributor yaitu, google main service dan Open Handset distribution (OHD) [11]. Aplikasi Android yang dibangun akan menjadi media yang membantu masyarakat luas dalam mencari informasi tentang kain songket Palembang [12].

Perangkat lunak ini akan dibuat sebagai aplikasi berbasis mobile yang menggunakan platform android. Untuk membangun aplikasi ini perlu dilakukan perekayasaan Perangkat Lunak agar aplikasi yang dihasilkan sesuai dengan kebutuhan pengguna. Salah satu tahap yang harus dilakukan dalam perekayasaan perangkat lunak adalah Perancangan [13]. Perangkat Lunak ini akan dirancang dengan Metode Waterfall yang meliputi tahap tinjauan pustaka, analisis kelemahan, kebutuhan dan kelayakan sistem, perancangan sistem, pembuatan aplikasi, pengujian aplikasi dan implementasi [14]. Perancangan Aplikasi electronic Museum (e-museum) sebagai media promosi songket Palembang berbasis android merupakan rancangan yang dapat diimplementasikan menjadi sebuah aplikasi yang dapat memberikan informasi tentang berbagai hal yang berkaitan dengan Songket Palembang. Selain sebagai media promosi, aplikasi yang dihasilkan dapat menjadi pengganti Museum songket konvensional jika masyarakat ingin mengetahui lebih banyak tentang songket Palembang mulai dari motif, ragam hias maupun peralatan pembuatan atau penenunan kain tersebut.

\section{PENELITIAN YANG TERKAIT}

Penelitian yang terkait dengan perancangan, pembangunan ataupun pengembangan aplikasi museum yang berbasis teknologi informasi telah cukup banyak dilakukan. Pada Penelitian sebelumnya yang dilakukan oleh Syarifah, N.A (2014), yang berjudul Pembuatan Aplikasi e-museum pada Museum Bahari Yogyakarta [15]. Penelitian ini menghasilkan aplikasi yang berbasis desktop yang interaktif bagi para pengunjung museum. Dengan Aplikasi e-museum ini para pengunjung bisa mengoperasikan aplikasi tersebut untuk mengetahui lebih detail tentang sejarah museum dan koleksi-koleksi yang ada di museum, sehingga dengan adanya aplikasi tersebut bisa menambah daya tarik bagi para pengunjung yang datang ke museum Bahari Yogyakarta.

Penelitian lain dilakukan oleh Rentor, Mario Fernando (2013) dengan judul Rancang Bangun Perangkat Lunak Pengenalan Motif Batik Berbasis Augmanted Reality [16]. Penelitian ini bertujuan untuk mengembangkan suatu aplikasi pengenalan motif batik berbasis augmented reality. Aplikasi ini dibuat dengan Vuforia SDK sebagai alat untuk mengembangkan Augmented Reality dengan Java, C++ berbasis Android. Aplikasi ini dapat digunakan ketika pengguna ingin membeli batik dan ingin tau motif atau makna yang terkandung dalam batik dengan mengarahkan ponsel androidnya ke batik tersebut.

Selanjutnya penelitian yang dilakukan oleh Saputro, Erlis Dwi (2015) dengan judul Augmented Reality Based e-musuem for Promotion Tool of Museum Radya Pustaka [17]. Penelitian ini menghasilkan sebuah aplikasi interaktif $e$ museum berbasis Augmented Reality yang dapat membantu pengunjung dalam memperoleh informasi mengenai bendabenda koleksi museum dan sebagai media promosi bagi museum Radya Pustaka.

Penelitian lain yang berjudul Aplikasi Pengenalan Batik Pesisir di Pulau Jawa Berbasis Android yang dilakukan Widianti, Linda Wahyu (2017) [18]. Pada penelitian ini menghasilkan aplikasi yang dapat memudahkan para penggemar batik untuk mengenal motif batik dari pesisir pulau jawa. Artikel penelitian ini telah dimuat pada jurnal Ilmiah Komputasi STMIK Jakarta STI\&K Desember 2017.

Pada Penelitian ini Perancangan e-museum ditujukan untuk mengenalkan songket sebagai bagian dari budaya Palembang lengkap dengan informasi yang berkaitan antra lain Peta dan denah lokasi yang menunjukkan sentra lokasi kerajinan songket, Detail item yang menggunakan fasilitas Image, Audio dan Video

\section{METODE PENELITIAN}

Penelitian ini diawali dengan perencanaan agar penelitian yang dilakukan dapat berjalan dengan baik sesuai dengan waktu yang ditetapkan serta tujuan penelitian dapat tercapai. Penelitian ini dilakukan melalui 2 tahap kegiatan yaitu; Analisis Sistem dan Perancangan [19]. Tahapan kegiatan ini merupakan bagian dari tahapan pada Waterfall Model yang 
merupakan bagian dari model Software Development Life Cycle (SDLC) yaitu proses mengembangkan atau mengubah suatu sistem perangkat lunak dengan menggunakan modelmodel dan metodologi yang digunakan orang untuk mengembangkan sistem-sistem perangkat lunak sebelumnya (cara-cara yang sudah teruji dengan baik) [14]. Berdasarkan Gbr 1, penelitian ini melaksanakan kegiatan penelitian pada tahap analisis dan desain.

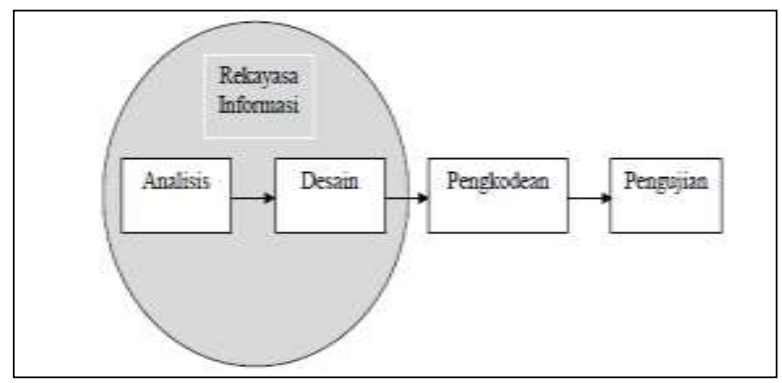

Gbr.1 Waterfall Model

\section{A. Analisis Sistem}

Tahap awal penelitian dimulai dari analisis system melalui kegiatan pengumpulan data. Penelitian ini menggunakan metode pengumpulan data observasi, wawancara dan Studi Literature. Observasi merupakan kegiatan ilmiah empiris yang mendasarkan fakta-fakta lapangan maupun teks, melalui pengalaman panca indera tanpa menggunakan manipulasi apa pun [20]. Sedangkan wawancara adalah teknik pengumpulan data yang digunakan untuk mendapatkan informasi langsung dari sumber tertentu. Teknik pengumpulan data dengan metode studi literature dilakukan dengan cara mengumpulkan data-data yang diperoleh dari berbagai sumber pustaka, antara lain media cetak, buku referensi ataupun melalui internet yang berkaitan dengan songket Palembang.

Berdasarkan analisis system yang sudah ada dan berjalan saat ini maka aplikasi yang dirancang memiliki 2 pengguna yaitu admin dan pengguna (User). Admin bertugas melakukan mengelola aplikasi, mulai dari perawatan aplikasi, berinteraksi dengan pengguna melalui menu FAQ, melakukan update data (berita, informasi, gambar) yang berkaitan dengan songket Palembang. Sedangkan pengguna (user) dapat melakukan pencarian informasi yang berkaitan dengan kain songket Palembang.

\section{B. Perancangan Sistem}

Berdasarkan hasil analisis Kebutuhan yang dilakukan pada tahapan analisis, maka dilakukan kegiatan desain sistem untuk dapat menentuan kebutuhan perangkat lunak dan perangkat keras system yang akan dibangun agar system yang dihasilkan dapat benar benar sesuai dengan kebutuhan. Use Case Diagram merupakan permodelan untuk prilaku (behavior)perangkat lunak yang akan dibangun. Use Case Diagram menjelaskan sebuah interaksi antara satu atau lebih aktor dengan perangkat lunak yang dibangun. Aktor merupakan pengguna yang akan berhubungan langsung dengan perangkat lunak yang dibuat. Sedangkan use case merupakan kegiatan yang dilakukan oleh aktor. Gbr 2 menampilkan use case dari sistem yang akan dirancang.

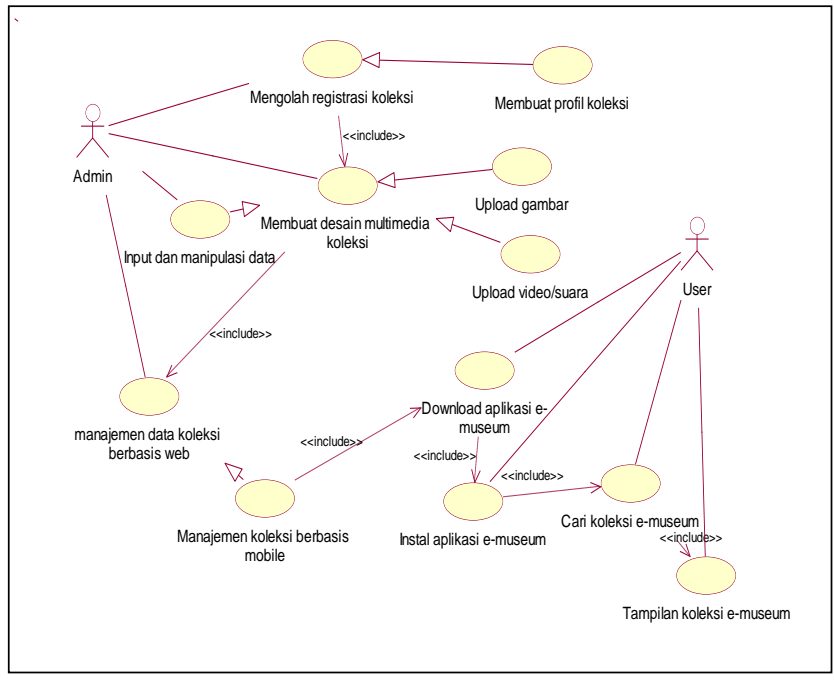

Gbr.2 Use Case Diagram

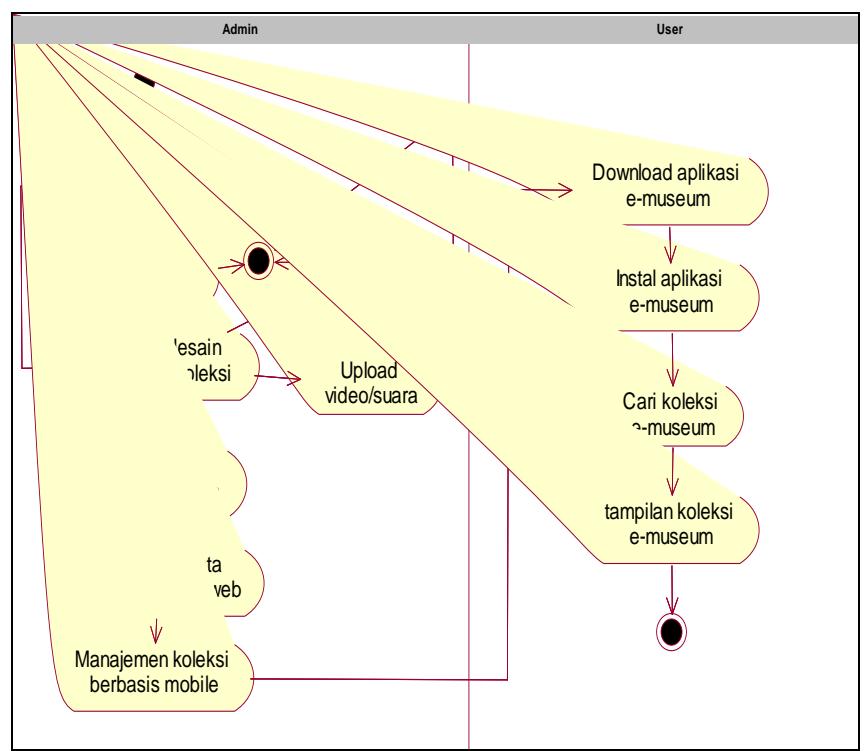

Gbr.3 Activity Diagram

Berdasakan rancangan use case yang telah dibuat, selanjutnya alur kegiatan sistem yang akan dibangun dirancang dalam diagram aktivitas (Activity Diagram). Activity diagram yang dibuat ini merupakan implementasi dari use case diagram. Hasil rancangan diagram activity sistem dapat dilihat pada Gbr 3. Berdasarkan activity diagram yang dirancangan seperti yang terlihat pada Gbr 3 dapat diketahui bahwa aktivitas admin adalah mengelola system yang nantinya akaan dibangun. Mulai dari megelola data koleksi, memanipulasi data dan memanajemen data. Sedangkan aktivitas Pengguna (user) dalam system yang adalah melihat atau mencari informasi yang dibutuhkan berkaitan dengan Songket Palembang.

\section{Pengujian Sistem}

Penelitian ini terbatas pada perancangan Aplikasi $e$ museum songket yang nantinya dapat diimplementasikan menjadi aplikasi e-museuem songket Palembang. Pada 
pembahasan penelitian ini belum dilaksanakan pengujian software karena baru menghasilkan perancangan antar muka system aplikasi yang akan dibangun. Pada saat perancangan aplikasi ini sudah diimplementasikan menjadi sebuah Perangkat Lunak e-musuem Songket Palembang, perlu dilakukan pengujian Sistem untuk mengetahui performance dari aplikasi e-musuem tersebut baik dari sisi Struktural maupun Fungsional aplikasi tersebut. Untuk melakukan pengujian tersebut dapat menggunakan metode Whitebox dan Metode blackbox. Metode whitebox digunakan untuk menguji Software atau Program Aplikasi yang telah dibuat yang menyangkut security dan performance program aplikasi tersebut yang meliputi antara lain tes code, implementation design, security, data flow dan software failure.

Pengujian kedua adalah dengan menggunkan metode blackbox, yaitu pengujian yang didasarkan pada fungsi fungsionalitas dan output. Pengujian Blackbox ini lebih ditujukan pada Desain software untuk melihat apakah ada celah bug atau vulnerabilitas yang dialami oleh program aplikasi. Blackbox Testing dilakukan setelah dilakukan whitebox Testing.

\section{HASIL DAN PEMBAHASAN}

Hasil dari penelitain ini adalah rancangan antarmuka aplikasi e-museum Songket Palembang yang dapat menjadi pengganti museum songket yang masih bersifat konvensional untuk memberikan berbagai informasi yang berkaitan dengan songket Palembang. Kemampuan dalam merancang antarmuka harus disesuaikan dengan kebutuhan serta kemampuan pengguna sehingga sistem yang dibangun dapat berjalan sesuai dengan fungsi yang diharapkan [21]. Pengalaman dalam merancang antamuka penguna, kreativitas dan kemampuan menganalisis merupakan hal dasar yang harus dimiliki pada saat merancangan antarmuka sistem.

\section{A. Perancangan Antarmuka}

Untuk memudahkan dalam membangun aplikasi $e$ museum sebagai media promosi Kain Songket KHas Palembang, perlu dilakukan proses perancangan interface (antarmuka) antar pengguna dan system yang nantinya akan diimplementasikan pada saat membangun perangkat lunak. Perancangan antarmuka akan sangat berdampak pada masyarakat terutama bagi user yang akan menggunakan aplikasi ini. Prinsip-prinsip yang digunakan dalam mendesain antamuka adalah sebagai berikut [22]:

1) User Competibility, yaitu kesesuaian tampilan dengan karakteristik dari user

2) Product Compatibility, Aplikasi yang dihasilkan harus memiliki tampilan yang sama.

3) Task Compatibity, Antarmuka yang dirancang harus sesuai dengan kebutuhan user, agar aplikasi yang telah diselesaikan bisa berjalan dengan efektif.

4) Work Flow Compatibility, artinya dalam satu halamn menu, pengguna (user) bisa melakukan berbagai aktifitas terhadap aplikasi yang akan dibangun, sebagi contoh aktivitas membuat komentar.

5) Consistency dan Familiarty, artinya aplikasi konsisten terhadap menu-menu yang telah tersedia, dan jikadidalam menu terdapat ketidaksesuaian maka user bisa menulis saran di kolom komentar
6) Control, hal ini menunjukkan bahwa aplikasi yang dibangun memiliki control terhadap user sehingga user telah dibatasi dalam menggunakan aplikasi.

7) Flexibility dan Responsiveness, artinya aplikasi yang telah dirancang bisa digunakan pada semua android.

8) Invisible Technology, yaitu menyembunyikan detail teknis dari suatu system seperti kode-kode program.

9) Robustness, aplikasi dapat mengatasi error bila user telah melakukan kesalahan contohnya terjadinya error pada saat terlalui banyak aplikasi yang digunakan pada perangkat android.

10) Ease of Learning, diharapkan pengguna (user) yang ingin menggunakan aplikasi ini tidak akan mengalami kesulitan.

11) Ukuran gambar yang meyesuaikan keadaan layar android, tidak terlalui besar ataupun terlalu kecil.

12) Penggunaan warna yang lembut pada aplikasi sehingga tidak membuat mata menjadi perih.

\section{B. Website Interface}

Website Interface adalah rancangan antarmuka yang dibuat untuk diimplementasikan pada sisi website yang akan menjadi media interaksi antara web dengan user. Website yang akan dibangun akan menajdi data base server yang terintegrasi dengan Aplikasi Mobail Android yang akan dibangun nantinya.

Gbr 4 menampillkan fitur aplikasi electronic museum (emuseum) yang manjadi antarmuka media dari website yang akan menjadi fitur penyampaian sumber informasi semua hal yang berkaitan dengan songket sebagai kain khas Palembang.

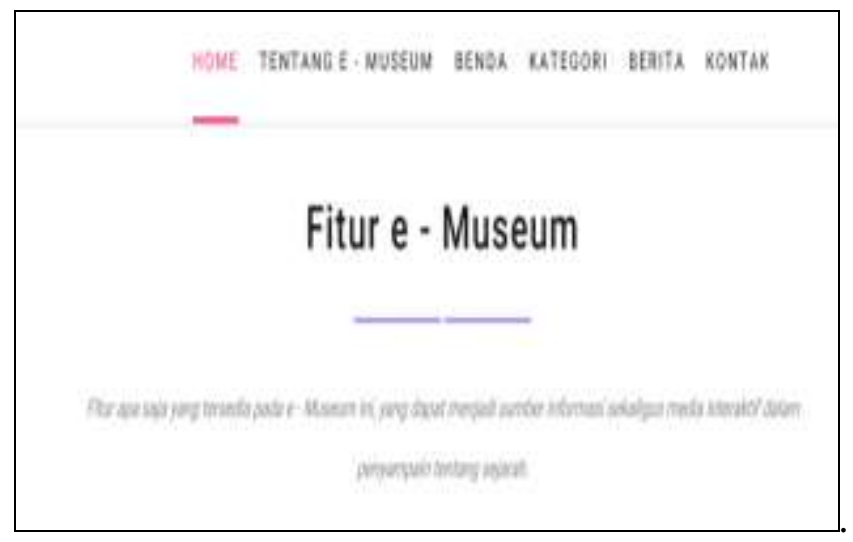

Gbr. 4 Antar Muka Fitur Aplikasi

Untuk menambah koleksi yang ada didalam aplikasi museum elektronik berbasia android ini, dirancang antamuka (interface) untuk Fitur Katalog yang merupakan media informasi mengenai semua koleksi yang akan dapat diakses secara online pada aplikasi yang akan dibangun. Gbr 5 menapilkan fitur katalog dalam aplikasi pada sisi website 


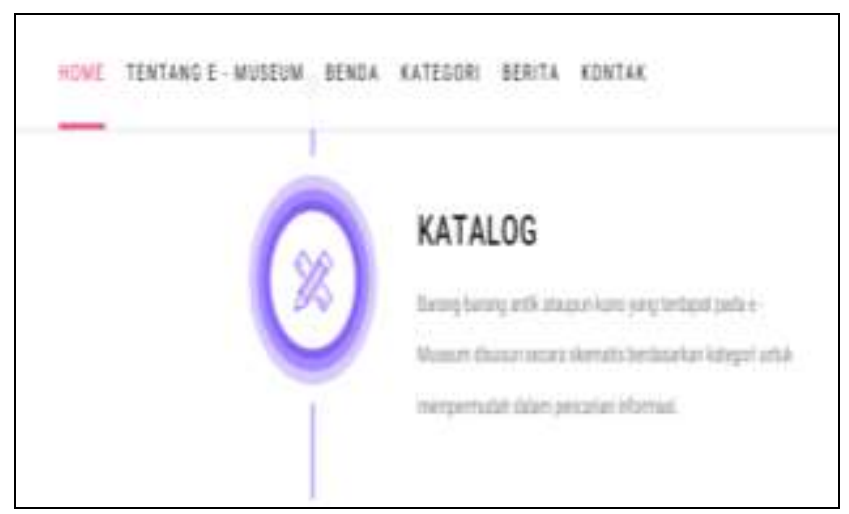

Gbr. 5 Antar Muka Fitur Katalog

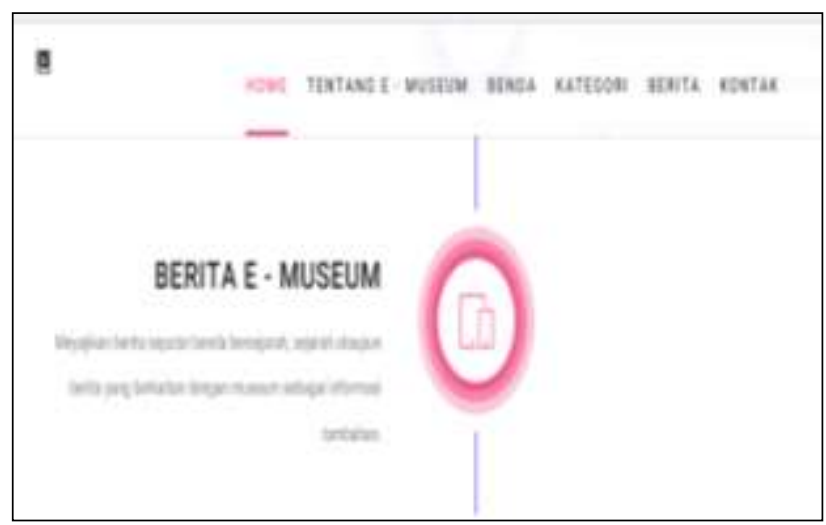

Gbr. 6 Antar Muka Fitur Berita

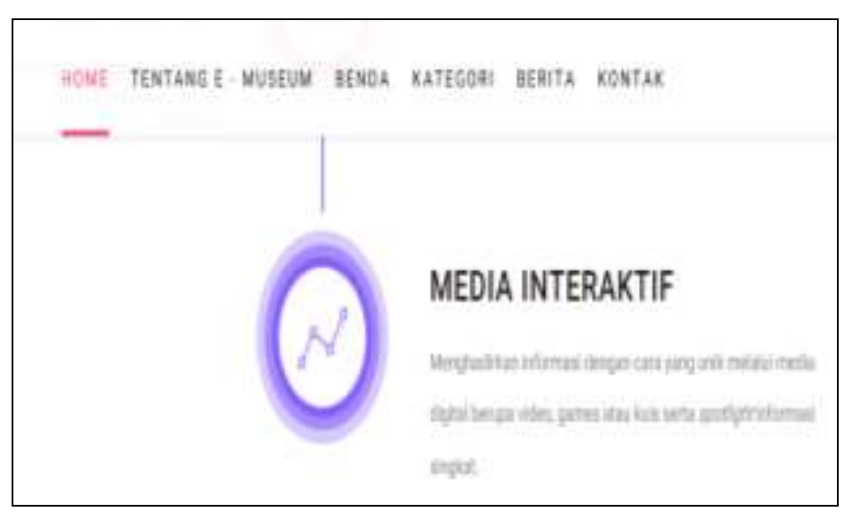

Gbr. 7 Antar Muka Fitur Media Interaktif

Fitur berita merupakan fitur yang digunakan untuk menambahkan berita pada aplikasi android yang akan dibangun. Fitur ini digunakan untuk memberikan informasiinformasi terbagru yang akan ditampilkan pasa aplikasi museum elektronik berbasis android. Informasi yang diberikan terutama yang berkaitan dengan kebudayaan Palembang. Tampilan fitur Berita pada aplikasi data dilihat pada Gbr 6.

Fitur lain yang ada pada sisi website dalam aplikasi adalah fitur media interaktif yang akan digunakan sebagai media interaksi antara aplikasi dengan user. Fitur ini akan memanfaatkan media digital berupa gambar, audio visual dan video terkait dengan koleksi yang tersedia dalam aplikasi nantinya. Gbr 7 menampilkan fitur media interaktif pada sisi website.

\section{Android System Interface}

Android System Interface adalah rancangan Antarmuka yang digunakan sebagai media interaksi antara perangkat aplikasi berbasis android dengan pengguna (user). Aplikasi berbasis android dapat membantu membrikan kemudahan bagi pengguna (user) untuk berinteraksi dengan aplikasi tersebut. Terutama dalam mendapatkan informasi yang diinginkan berkaitan dengan songket Palembang. Rancangan tampilan awal aplikasi pada system android yang akan dibangun dapat dilihat pada Gbr 8. Tampilan awal pada aplikasi atau splash Screen merupakan tampilan yang dapat dilihat pada saat aplikasi dijalankan.

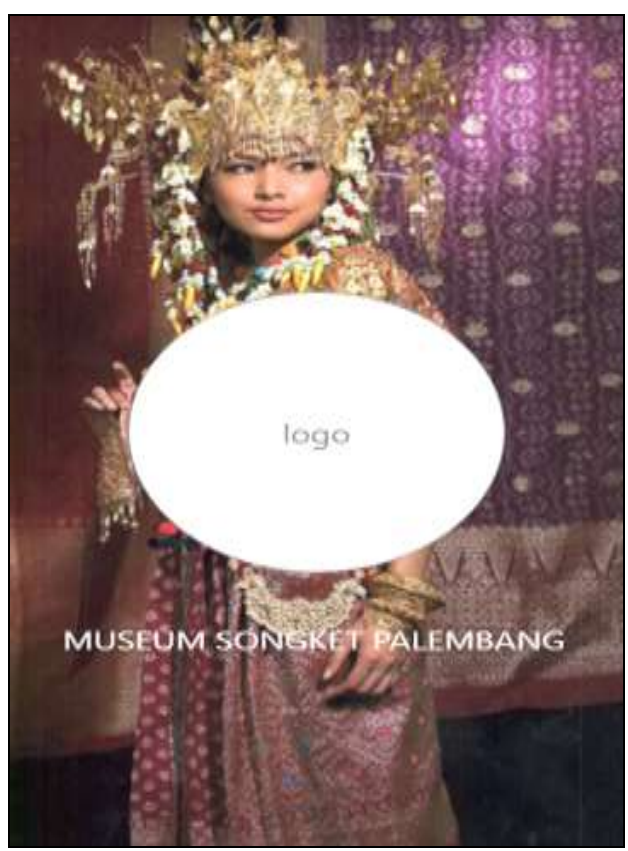

Gbr. 8. Rancangan Tampilan Awal Aplikasi pada Sistem Android

Setelah Halaman awal aplikasi tampil, maka pengguna akan langsung masuk ke dalam menu aplikasi. Rancangan tampilan utama aplikasi akan menampilkan fitur-fitur yang dapat digunakan oleh pengguna (user) pada aplikasi museum elektronik berbasis android yang akan dibangun. Gbr 9 menampilkan dashboard теnи (Tampilan utama) pada sistem android dari aplikasi. 


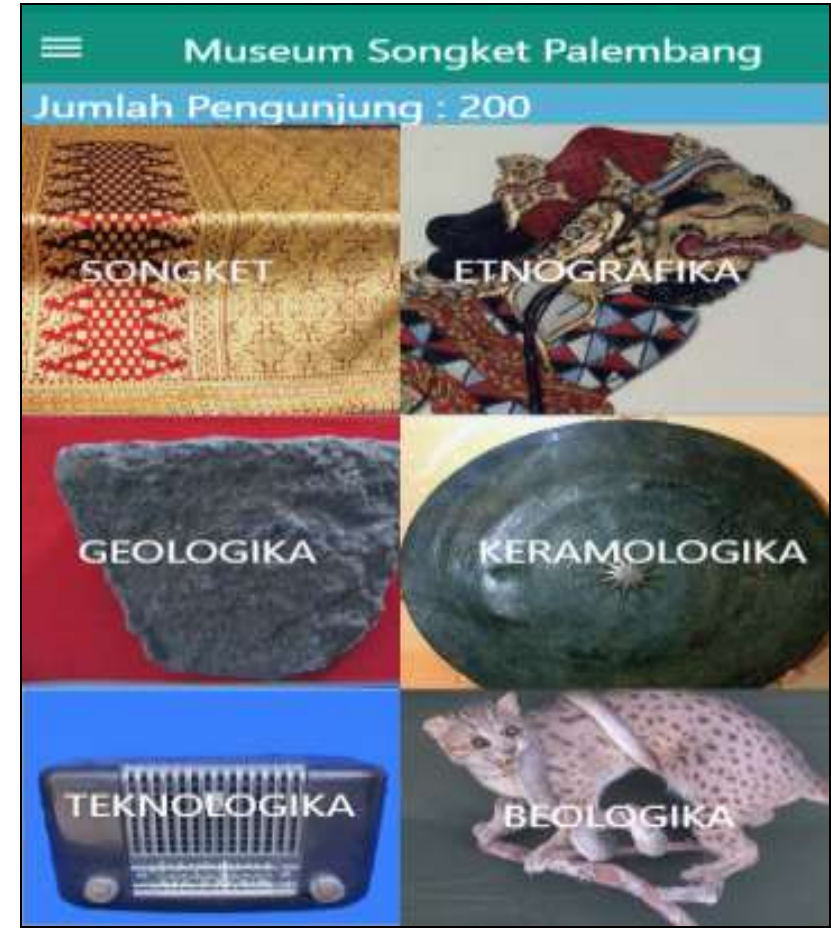

Gbr. 9 Rancangan Tampilan dashboard menu pada Sistem Android
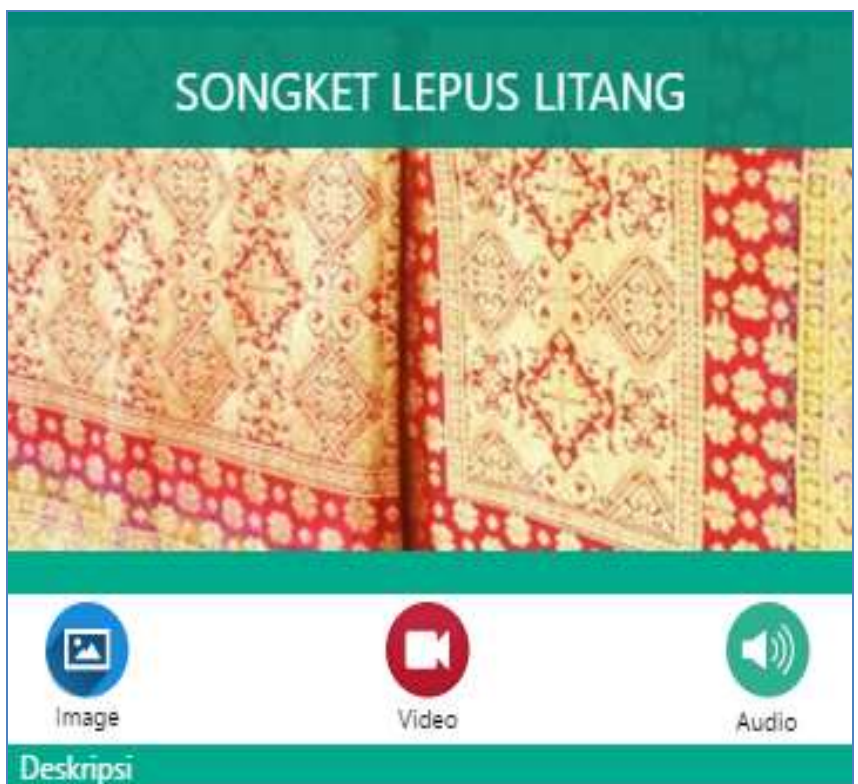

Lepus kurang lebih artinya menutupi, Songket yang benang emasnya hampir menutupi seluruh bagian kain. Sesuai

Gbr. 10 Tampilan Detil item koleksi pada Sistem Android

Rancangan detil item adalah rancangan untuk halaman yang memberikan detil spesifik mengenai koleksi yang ada dalam museum elektronik. Detil item untuk koleksi $e$-museum ini akan dilengkapi dengan gambar, suara dan video yang berkaitan dengan koleksi tersebut. Gbr 10. Menampilkan rancangan halaman detil item koleksi dari museum elektronik.
Rancangna pada fitur pendukung aplikasi merupakan fitur yang akan menampilkan informasi yang terkait dengan koleksi yang ada pada aplikasi. Pada fitur ini akan di berikan informasi peta lokasi museum songket Palembang, lokasi sentra kerajinan songket Palembang, FAQ dan hal-hal lain yang berkaitan dengan informasi tentang songket Palembang. Gbr 11 merupakan tampilan rancangan fitur pendukung pada aplikasi ini.

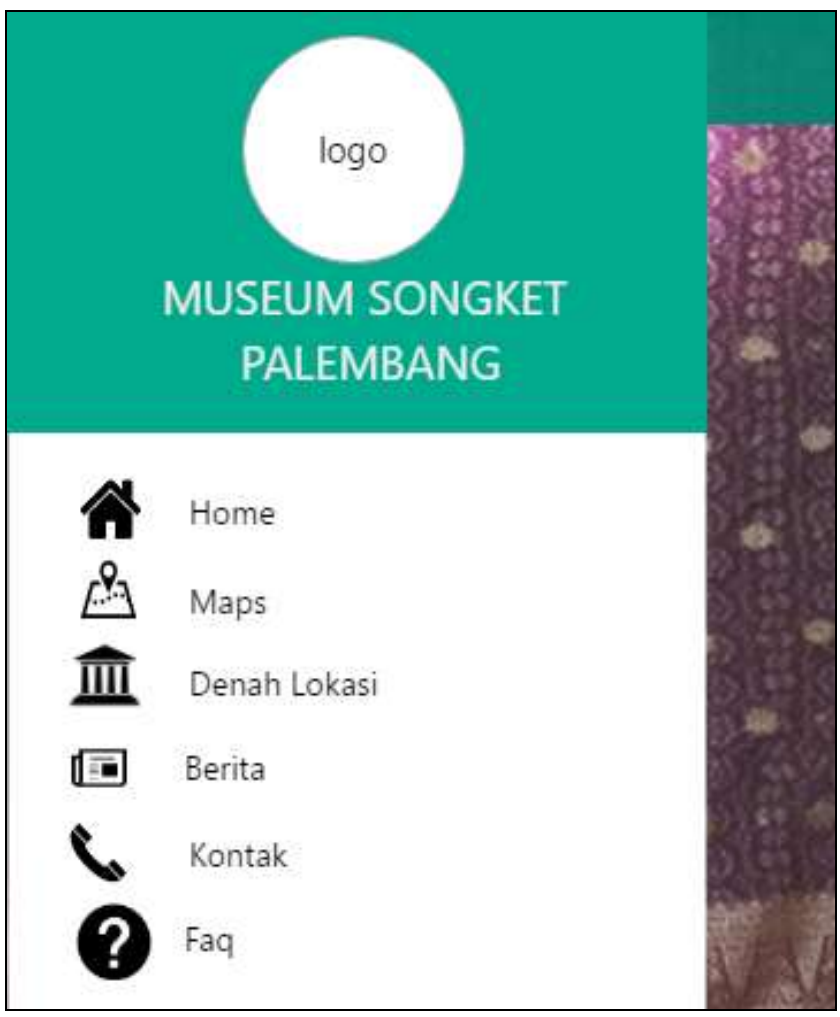

Gbr. 11 Tampilan rancangan fitur pendukung aplikasi pada system android

\section{KESIMPULAN}

Penelitian ini menghasilkan sebuah rancangan system berupa use case Diagram dan activity diagram yang menggambarkan prilaku perangkat lunak yang nantinya akan dibangun dan activity Diagram yang menggambarkan alur kegiatan system yang nantinya akan dibangun. Berdasarkan rancangan system tersebut dapat diketahui bahwa dalam interaksi dalam system terjadi antara dua (2) actor yaitu pengguna (user) dan administrator (admin). Selain itu dalam penelitian ini juga dihasilkan rancangan antarmuka pada sisi website (Website Interface) dan Antarmuka pada sisi perangkat android (Android system interface) yang saat diimpelemntasikan pada aplikasi yang akan dibangun dapat membantu pengguna ataupun Admin untuk berinteraksi dengan sistem.

Agar Aplikasi yang nantinya dihasilkan tidak mengandung error atau kesalahan maka perlu dilakukan evaluasi kembali sebelum masuk ketahap berikutnya. Hal ini bertujuan agar Aplikasi yang dihasilkan dapat memberikan informasi yang dibutuhkan sesuai dengan tujuan dan manfaat yang telah dirumuskan sebelumnya. 


\section{UCAPAN TERIMA KASIH}

Penelitian dalam makalah ini secara finansial didukung oleh Kementrian Riset, teknologi, dan pendidikan tinggi, Indonesia. Kami juga ingin mengucapkan terima kasih kepada Lembaga Penelitian dan Pengabdian Masyarakat, Universitas Bina Darma Palembang yang ikut mendukung terlaksananya kegiatan penelitian ini.

\section{DAFTAR PUSTAKA}

[1] A. Akbar, A. Solihat, and Kiftiawati, Museum di Indonesia: kendala dan harapan. Papas Sinar Sinanti, 2010

[2] Direktorat Jendral Sejarah dan Purbakala, Pedoman Museum Indonesia. Departemen Kebudayaan dan Pariwisata, 2008.

[3] N. Magetsari, "Pemaknaan Museum untuk Masa Kini," in Diskusi dan Komunikasi Museum, 2009, pp. 4-7.

[4] F. F. J. Schouten, Pengantar Didaktik Museum. Jakarta: Direktorat Permuseuman, 1992

[5] A. W. Viatra and S. Triyanto, "SENI KERAJINAN SONGKET KAMPOENG TENUNDI INDRALAYA, PALEMBANG," Ekspresi Seni, vol. 16, no. 2, p. 168, Jul. 2014.

[6] Palembang Doeloe, sekarang dan akan datang. Palembang: Direktori Kesenian Sumsel Palembang Djaja, 2008.

[7] Y. Syarofie, Songket Palembang: nilai filosofis, jejak sejarah, dan tradisi. Pemerintah Provinsi Sumatera Selatan, Dinas Pendidikan Nasional, Kegiatan Pengelolaan Kelestarian dan Pembinaan Nilai Budaya Sumatera Selatan, 2007.

[8] Soesandireja, "Kain Songket, Asal Mula, Jenis, dan Maknanya," 2015. [Online]. Available: http://www.wacana.co/2015/01/kain-songketasal-mula-jenis-dan-maknanya/. [Accessed: 17-Apr-2017].

[9] D. jenderal kekayaan intelektual kementerian hokum dan H. RI, "Hak Kekayaan Intelektual.” [Online]. Available: http://dgip.go.id. [Accessed: 20-Jun-2018]
[10] M. Yosef, Pemrograman Android Black Box. Jakarta: Jasakom, 2013.

[11] S. Elvrilla, "Augmented Reality Panduan Belajar Sholat Berdasarkan Buku Teks Belajar Sholat Menggunakan Android," 2012.

[12] N. K. Sumiari and P. Setyarini, "PERANCANGAN MEDIA PUBLIKASI KESENIAN TARI BALI BERBASIS WEB," Proc. Konf. Nas. Sist. dan Inform., vol. 0, no. 0, Oct. 2015.

[13] S. Adi Nugraha and R. Setiawan, "Perancangan Sistem Informasi Pengolahan Administrasi Keuangan Sekolah Menengah Pertama Islam Terpadu Assalam Garut," J. Algoritm., vol. 13, no. 1, p. 148, Oct. 1923.

[14] A. S. Rosa and M. Shalahuddin., Modul Pembelajaran Perangkat Lunak. Bandung: Modula, 2011.

[15] N. A. Syarifah, "Pembuatan Aplikasi E-Museum Pada Museum Bahari Yogyakarta," J. STMIK AMIKOM Yogyakarta, 2014.

[16] M. F. Rentor, "RANCANG BANGUN PERANGKAT LUNAK PENGENALAN MOTIF BATIK BERBASIS AUGMENTED REALITY," 2013.

[17] E. D. Saputro, "E-Museum Berbasis Augmented Reality Sebagai Media Promosi Museum Radya Pustaka,” 2015.

[18] Widianti and L. Wahyu, "Aplikasi Pengenalan Batik Pesisir di Pulau Jawa Berbasis Android," J. Ilm. KOMPUTASI, vol. 16, no. 3, pp. 187 194, 2017.

[19] J. HM, Analisis dan Desain ( Sistem Informasi Pendekatan Terstruktur Teori dan Praktek Aplikasi Bisnis ). Penerbit ANDI.

[20] H. Hasanah, "TEKNIK-TEKNIK OBSERVASI (Sebuah Alternatif Metode Pengumpulan Data Kualitatif Ilmu-ilmu Sosial)," AtTaqaddum, vol. 8, no. 1, p. 21, Jan. 2017.

[21] T. W. Oktaviani, "Perancangan User Interface Berbasis Web untuk Home Automation Gateway Berbasis IQRF TR53B," J. Nas. Tek. Elektro dan Teknol. Inf., vol. 3, no. 3, 2014.

[22] W. O. Galitz, The essential guide to user interface design: an introduction to GUI design principles and techniques. Wiley Pub, 2007 